doi:10.4149/neo_2015_042

\title{
Modification of microflora imbalance: future directions in prevention and treatment of colorectal cancer?
}

\section{Minireview}

S. CIERNIKOVA ${ }^{1, *}$, M. MEGO ${ }^{2}$, K. HAINOVA ${ }^{1}$, Z. ADAMCIKOVA ${ }^{1}$, V. STEVURKOVA ${ }^{1}$, V. ZAJAC ${ }^{1}$

${ }^{1}$ Department of Cancer Genetics, Cancer Research institute, Slovak Academy of Sciences, Vlarska 7, 833 91 Bratislava, Slovakia; ${ }^{2}$ Department of Medical Oncology, Faculty of Medicine, Comenius University and National Cancer Institute, Klenova 1, 83310 Bratislava, Slovakia

${ }^{*}$ Correspondence: sona.ciernikova@savba.sk

Received December 18, 2014 / Accepted January 19, 2015

\begin{abstract}
Increasing incidence and mortality of colorectal cancer brings the necessity to uncover new possibilities in the prevention, diagnosis and treatment. The microbiome as the collective genetic material of the microflora, overexceed the number of genes in the human genome and is unique for each individual. Due to the benefits providing for the host and mainly for immediate interaction with the host immune system, a gastrointestinal microflora can be considered „cardinal microbiome“. Host-microbial relations includes symbiotic, pathogenic and competitive interactions. Causal role of gastrointestinal microflora in colorectal carcinogenesis is still not well determined. This minireview is focused on current evidence in understanding the role of bacteria in colorectal carcinogenesis, the impact of bacterial dysbiosis on tumor formation, and ability of probiotics and bacterial vectors to modulate the gastrointestinal microflora as prevention and therapy tool in colorectal cancer.
\end{abstract}

Key words: colorectal cancer, intestinal bacteria, microflora dysbiosis, cancer prevention and treatment, probiotics, bacterial vectors

\section{Gut microflora and human microbiome project}

The human gastrointestinal tract is colonized by a complex microbial community comprising thousands of bacterial strains that play an important role in the physiology of the host. Their number ten times exceeds the total number of somatic cells in the human body and represent $1.5-2 \mathrm{~kg}$ of total body weight [1]. Moreover, it is estimated that collective microflora genetic material (including bacteria, archaea, viruses and eukaryotes), microbiome, harbours 100 times more genes than the human genome [2].

The composition of the intestinal microbiota varies substantially amongst individuals but both culture-dependent and independent studies have demonstrated that the majority of the intestinal bacteria of adult man belong to two phyla, the Bacteroidetes and the Firmicutes [3]. Breast-feeding infants tends to contribute to higher levels of bifidobacteria ranging from 60 up to $90 \%$ of the total faecal microbiota $[4 ; 5]$. Microflora undergoes a more dramatic change and becomes diverse after solid food introduction resulting in an adult-like microbiota approximately by the age of 2 [6]. Afterwards, the intestinal microflora remains relatively stable during adult life [7].

Different microbes are found at appropriate sites of gastrointestinal tract reflecting the environment changes along it. While lower part of the gastrointestinal tract with slow food passage allowed establishing a large microbial community reflecting its anaerobicity, bacterial flora in upper part is less abundant. Furthermore, dramatic differences develop between the luminal and the mucosal microflora composition taking into account mucosal microaerobic environment and secretion of lysozyme and defensis by Paneth cells [8].

The complexity of interactions between gastrointestinal microflora and human intestinal cells is intensively stud- 
ied. Previous knowledge about bacterial diversity has been obtained by selective culturing of microorganisms from faecal samples. However, limited information about bacterial communities directly associated with colon mucosa was available so far. New metagenomics approaches overcome the problem with bacterial cultivations and open up opportunities for a detailed examination and comparison of healthy subjects microflora versus bacteria from cancer patients. Currently, Human Microbiome Project (HMP) belongs to the most comprehensive research projects worldwide [9]. HMP mission is to generate the research resources enabling characterization of the human microbiota and analysis of their role in human health and disease [10]. After The HMP Consortium has reported the structure and function of the human microbiome in 300 healthy adults at 18 body sites from a single time point $[11,12]$, the significant associations between community types and whether the subject was ever breastfead, gender and education level was observed. Moreover, data analysis has shown different bacterial types observed in oral and gut microbiomes, but the specific taxonomic compositions at these sites were predictive of each other. The community types from sites within the oral cavity were the least stable, whereas those in the vagina and gut were the most stable [13].

Commensal bacteria provide several benefits to its host and play an important role in the development and functioning of the intestinal immune system. Futher, they are actively involved in the development and maturation of the intestinal mucosa, in prevention against infections caused by pathogenic bacteria, as well as in vitamin synthesis and metabolic degradation [14]. In addition to the absorption of nutrients, protection against pathogen, their colonization contributes to the regulation of cellular proliferation, differentiation and expression of genes in host epithelial cells. Bacterial regulation of the intestinal epithelial differentiation factors Hes1, Hath1 and KLF4 was found in the colon adenocarcinoma cell line LS174T. Expression of Hes1 and Hath1, and to a minor degree also of KLF4, was reduced by E. coli K-12 and E. coli Nissle 1917. In vivo experiments on specific pathogen free and conventionalized mice as compared to germ free mice confirmed the results by a diminished colonic expression of Hath1 and KLF4 [15].

\section{Gastrointestinal microflora in etiology of colorectal cancer}

Approximately 70\% of colorectal cancer cases develop spontaneously and are of unknown etiology [16]. Several studies focused on identification of bacterial composition in healthy individuals and patients confirm that the intestinal microflora constitution and structure can lead to the colorectal polypspremalignant development $[17,18]$. Globally, it is estimated that approximately $20 \%$ of all malignancies have infectious background with a total number of 1.2 million cases per year
[19]. One of the most striking association is a link between Helicobacter pylori and gastric adenocarcima [20] as well as mucosa-associated lymphoma [21].

Dysbiosis in intestinal microflora can promote both chronic inflammatory conditions and the production of carcinogenic metabolites, leading to neoplasia. However, it is still not exactly clear how bacteria influence the formation of colorectal adenomas and carcinomas.

From complex point of view, bacterial contribution involve interplay between chronic inflamation, direct effect of microbiota on host cell signaling and cell biology, and tissue stem-cell homeostasis [22]. Growing evidence suggests that the colonic microflora play a critical role in regulating several host functions important to tumor formation such as intestinal epithelial cell homeostasis, barrier function, mucosal immune responses, and host metabolism. Inflammation, use of antibiotics and host factors change the intestinal environment towards bacterial dysbiosis by alternation of normal homeostasis between the host organism and intestinal bacteria [23]. According to the large epidemiological studies, increased risk of colorectal cancer may be associated with the consumption of red meat and animal fat [24], whereas the diet rich in fruits and vegetable seems to have a protective effect [25]. The intestinal microflora imbalance may represent a link between diet and tumorigenesis.

Recent analysis of the gut microbiome from stool samples of patients representing different stage of colorectal cancer development: healthy, adenoma, and carcinoma, revealed both an enrichment of pathogenic bacteria (Fusobacterium and Porphyromonas spp.) and also the depletion of potencially protective species (genera Clostridium and Bacteroides) contribute to colorectal cancer pathology [26]. Animal and tissue culture-based studies and more important, also clinical studies reported that Fusobacterium spp. were enriched on the surface of tumors comparing to appropriate healthy tissue controls $[27,28]$. C. rodentium infection promotes adenoma formation in the colon of $A p c^{\mathrm{Min} /+}$ mice induced by hyperproliferative state. Moreover, $C$. rodentium produces attaching and effacing (AE) lesions in mice descending colon [29] similar to AE lesions generated by the human pathogens enteropathogenic (EPEC) and enterohemorrhagic (EHEC) E. coli, respectively. Hence, this model system may serve to study the contribution of AE lesion formation to infection and disease [30]. Besides the animal models, epidemiologic studies also support the causative role of several bacterial pathogens in etiology of colorectal cancer. Streptococcus bovis, Escherichia coli, and Fusobacterium spp. showed to be directly linked to colon cancer [31-33]. Bacterial profile of patients with the adenomas occurrence showed an increased frequency of bacterial genera such Faecalibacterium, Shigella and Proteobacterium and reduced frequency of Bacteroides and Coprococcus, at the other hand. Contrary, phylum Firmicutes, Bacteroidetes have been dominating in healthy subjects [34].

The presence of adherent and intracellular bacteria in tumor cells. The research focused on characterization of ad- 
herent and enteropathogenic bacteria outlined their possible role in the development of colorectal adenomas and carcinomas in patients when comparing to healthy controls [35]. In our study on a cohort of 172 biopsy specimens from 60 patients (colon cancer, $n=10$ patients; colonic adenoma, $n=20$; control group, $n=20$; cancer patients without gastrointestinal tract GIT malignancy, $n=10)$ examined with the gentamycin protection assay (GPA), the number of biopsies with intracellular bacteria was significantly higher in adenoma and carcinoma group than in control group (26vs. $10 \% ; p=0.004)$. Futher, the difference in cancer patients without GIT malignancy was nonsignificant [36]. Recently, the studies on colorectal cancer patients exhibit bacteria adhering to tumor tissue and provide an indirect evidence of bacterial invasion $[37,38]$.

The possibility of horizontal gene transfer between bacteria and mammalian cells Enormous size of the human microbiome and intimate proximity between intestinal bacteria and colon epithelial tissue raises the question of opportunity for horizontal gene transfer to somatic cells. Although common among bacteria, horizontal gene transfer allowing the gene movement between bacteria and eukaryotes seems to be a rare event. Several studies have reported in vitro gene transfer from intracellular bacteria to mammalian phagocytic and non-phagocytic cells [39, 40]. Many of in vivo bacteria to animal transfers occur as part of intimate relationship between prokaryotic endosymbionts and their host, potentially providing a mechanism for acquisition of new genes and functions [41, 42]. A few eukaryote to bacteria transfers have been described so far. Legionella pneumophila has been found to encode more than 100 eukaryotic-like proteins revealing that 29 are of eukaryotic ancestry [43]. Phylogenomic survey of putative horizontal gene transfer events in Methanosphaera stadtmanae indicated a substantial fraction of the proteins which were involved in inter-domain horizontal gene transfer [44]. Recent data from microbiome project have showed that bacterial DNA integrates into the human genome through somatic RNA intermediate and this integration is more common in tumor samples [45].

Analyses of bacteria isolated from familial adenomatous polyposis (FAP) patients revealed the presence of APC-like sequences showing more than $90 \%$ sequence homology with human Adenomatous polyposis coli (APC) gene. The expression of APC-like sequences was demostrated by Western blot analysis and bacterial transcripts containing the part of exon 15 of the APC gene by reverse transcription-PCR indicated that an $A P C$ gene derived fragment may be produced. Almost $90 \%$ of tested bacteria were identified as E.coli $[46,47]$.

\section{Probiotics in modulation of disorders characterized by microbial dysbiosis}

Experimental and clinical studies have shown that dysbiosis in gastrointestinal microflora can be modulated by the effect of probiotics. According to the classification, probiotics are live microorganisms which, when administered in adequate amounts, confer a health benefit on the host [48]. Their protective effect was confirmed in prevention and treatment of gastrointestinal tract diseases including irritable bowel syndrome, ulcerative colitis $[49,50]$, and reduction of gastritis by Helicobacter pylori infection [51]. Growing evidence suggests probiotic indication in diarrhea caused by subsequent excessive growth of Clostridium difficile after antibiotic therapy $[52,53]$ Moreover, a few studies indicate that probiotics can be effective in the prevention of radiation - induced diarrhea among cancer patients $[54,55]$.

The essential characteristic of probiotic bacteria is the ability to control inflammation via adhesion to the intestinal mucosa cells, allowing competitive pathogens displacement. In a model of pathogen-induced inflammation, treatment of mice with Bifidobacteria infantis led to a down regulation of intestinal inflammation with increased number of CD4+CD25+ TReg cells78. Moreover, the adoptive transfer of the CD4+CD25+ TReg-cell population from mice fed with $B$. infantis inhibited inflammation-induced activation of nuclear factor- $\kappa \mathrm{B}(\mathrm{NF}-\kappa \mathrm{B})$ in recipient mice [56].

Probiotic bacteria are known to exert an anticancer activity in animal and tissue-culture studies. Bacillus polyfermenticus producing antimicrobial agent bacteriocin suppresses tumor growth as shown by inhibition of colon cancer cell growth, failure of colony formation, and reduced tumor volume of mouse xenograft model of human colon cancer. Moreover, ErB2 a ErbB3 inhibiton and decreased E2F-1 and cyclin D1 expression suggest a possibility that probiotic bacterium Bacillus polyfermenticus can be used as a chemopreventive therapy [57].

The outcomes of SYNCAN study have demonstrated that administration of Lactobacillus rhamnosus and Bifidobacterium animalis ssp. lactis BB- 12 in synbiotic combination with inulin enriched with oligofructose resulted in a significant reduction of colon cancer incidence, a significant increase in butyrate production, reduction in genotoxicity of faecal water, reduction of DNA damage and the stimulation of the immune system leading to the stimulation of NK-cells and increased levels of IL-10 produced in Peyer Patches [58]. Recently, a large 12 years of follow-up prospective study on 45,241 (14,178 men; 31,063 women) volunteers showed significant association between high yogurt intake and decreased colorectal cancer risk, suggesting that yogurt should be part of a diet to prevent the disease [59]. Streptococcus thermophilus and Lactobacillus delbrueckii subsp. bulgaricus are the two lactic acid bacteria traditionally used to produce yogurt from milk and their effect in preventing the initiation of carcinogenesis was previously confirmed even in animal models [60].

Decreasing the toxicity related to anticancer treatment, especially radiation therapy by probiotics represent a possible trend [reviewed in 61]. However, safety of probiotic use in immunocompromised cancer patients became an 
essential issue of the research these days. In our previous studies we have concern on determination of efficacy and safety of the probiotic strain Enterococcus faecium M74 enriched with organic selenium in neutropenic patients with solid and hematological malignancies. Alltogether, eleven patients were included in the study - six patients with germ cell tumors at first and five patients with relapse of acute leukemia after safety evaluation. The febrile episode was not observed in any of the patients. The gut colonization by enterococci reaches $10(6) \mathrm{CFU} / \mathrm{g}$ stool. In 5 patients with acute leukemia during 127 days of severe neutropenia, 12 febrile episodes has occurred. There was not noted any febrile episode or infection provoked by the tested strain. Tolerance of therapy was excellent without significant undesirable effects [62]. Based on these results, another study with fourteen myelogenous leukemia patients concerning on the prevention of febrile neutropenia by probiotic strain Enterococcus faecium M-74 enriched with selenium was performed. Our results demonstrated the safety of the probiotic strain used [63]. In our latest study, administration of probiotics in patients with colorectal cancer treated with irinotecan-based chemotherapy showed to be safe and could lead to a reduction in the incidence and severity of gastrointestinal toxicity [64].

Recently, the results from eleven randomised, controlled trials concerning on the efficacy of probiotics in people with cancer $(\mathrm{N}=1557$ participants) displayed reducing the severity and frequency of diarrhoea in patients with cancer and the requirement for anti-diarrheal medication, respectively. Nevertheless, seventeen studies $(\mathrm{N}=1530)$ included in the safety analysis five case reports showed probiotic-related bacteraemia/fungaemia/positive blood cultures [65]. Taken into account these findings, there is currently insufficient evidence about effectiveness and especially safety in people with cancer and futher analyses need to be evaluted.

\section{Bacteria as delivery systems in inflamation, tumor pre- vention and therapy}

To identify cancer therapy with high level of selectivity and limited toxicity to normal tissue is the key effort of cancer research. Systemically administered bacteria engineered to deliver therapeutic genes are specifically targeting to the tumors, either externally using non-invasive species or within the tumor cells when using virulence attenuated strains of pathogenic bacteria $[66,67]$. The specific nature of bacterial colonisation of tumors, by taking advantage of their unique physiology, may be exploited to aid cancer treatment in several ways.

Bacterial vectors may be use in two broad approaches according to their suitability for different therapeutic strategies; Tumor-specific bacterial replication resulting in alternative gene therapy (AGT) or intracellular plasmid transfer (bactofection).
Tumor hypoxia and even bacterial chemotaxis towards chemo-attractant compounds in necrotic regions can be suggested as a contributing factors for tumor targeting [68]. In alternative gene therapy (AGT), bacteria produce a therapeutic protein in cells „in situ“ or persist in intercellular spaces within the tumor environment which permits using of noninvasive strains $[69,70]$. After firstly reported Clostridium spp., tumor-specific replication has been demonstrated for Bifidobacterium spp, Salmonella spp, Escherichia coli, Vibrio cholerae and Listeria monocytogenes. It has been showns that systemic delivery of "therapeutic" bacteria can be achieved not only through intravenous but also through oral administration [71]. Delivery vector Escherichia coli BL21(DE3) and BL21(DE3) pLysS with complete sequence of APC gene was orally administered for restoration of truncated APC protein in APC+/APC1638N mice. Preliminary results showed the effect of bacterially expressed APC protein in elimination of intestinal polyps, but still more research is needed [72].

Bactofection presents a bacterial-mediated transfer of plasmid DNA to mammalian cells leading to expression of heterologous proteins in different mammalian cell types [73]. Successful gene expression requires entry of the bacterial vector followed by realease of plasmid DNA into the cellular environment. Moreover, bacterial vectors can be also paired with RNA interference, potentially providing a steady supply of siRNAs to sustain therapeutic benefits [74]. Bacterial entry can be allowed by the presence of transmembrane surface receptors - integrins, that are found on the surface of most mammalian cells. Various bacterial species including Salmonella spp., L. monocytogenes and E. coli have been examined as bactofection vectors $[75,76]$. DNA transfection reagents could increase the gene delivery efficiency of a bactofection vector that uses the integrin receptor. Lipofectamine reagent has improved the entry and internalization of invasive E. coli $\mathrm{DH} 10 \mathrm{~B}$ vector contained the Yersinia pseudotuberculosis invasin gene into HeLa cells. Futhermore, the addition of the Lipofectamine enhanced up to 2.8-fold green fluorescent protein (GFP) expression from a reporter plasmid. [77].

Colonisation of specific niches in the gut lumen with bacterial strains capable to modulate local inflammation and imunity could control gastrointestinal tract neoplasia. Their survival in human gastrointestinal tract is possible especially due to their origin. Application of bacterial vectors in clinical practise is possible only when using recombinantly prepared nonpathogenic strains. The advantage of this transfer is simplicity, specificity and efficiency of DNA transfer. Since cytokines are major mediators of inflammation and regulatory activity in the gut mucosa, the ability of Lactococcus lactis carrying the pValac:il-10 plasmid harbouring the anti-inflammatory cytokine IL-10 of Mus musculus to modulate the cytokines production in the colonic tissues of mice, was tested. Mice receiving plasmid construct showed significantly higher IL-10 levels comparing to control group of healthy ones. Moreover, achieved results showed that not 
only delivery of the pValac:il-10 plasmid by the invasive strain L. lactis MG1363 FnBPA+, but also by the non-invasive L. lactis MG1363 strain, was effective at diminishing intestinal inflammation [78]. Eukaryotic plasmid pValac allows cloning a particular gene of interest, expression of the molecule by host cells, replication both in E. coli and in L. lactis and bacterial selection via $\mathrm{Cm}$ resistance gene [79]. These characteristics designate it to be a possible therapeutic tool for disorders characterized bacterial dysbiosis as inflammatory bowel diseases, potentially for colorectal cancer as well.

\section{Conclusion}

A constantly growing evidence raises the questions of possible causal role of gastrointestinal microflora in the colorectal carcinogenesis. Recent studies point to the future direction towards microflora modification in prevention and even treatment of gastrointestinal cancers. Favorable, but also negative effects of bacteria on the host microorganisms physiology are still understudied. Human Microbiome Project will soon bring a comprehensive databases of microbial counterparts and key interactions between bacteria and human health may be uncovered.

Acknowledgements: The studies and our experiments mentioned in this study were performed with the kind support provided by the grants VEGA2/0096/11, VEGA 2/0170/13 and grant APVV06-46-11.

\section{References}

[1] BACKHED F, LEY RE, SONNENBURG JL, PETERSON DA, GORDON JI. Host-bacterial mutualism in the human intestine. Science 2005; 307: 1915-1920. http://dx.doi.org/10.1126/ science. 1104816

[2] TLASKALOVA-HOGENOVA H, STEPANKOVA R, KOZAKOVA H, HUDCOVIC T, VANNUCCI L et al. The role of gut microbiota (commensal bacteria) and the mucosal barrier in the pathogenesis of inflammatory and autoimmune diseases and cancer: contribution of germ-free and gnotobiotic animal models of human diseases. Cellular \& Molecular Immunology 2011; 8: 110-120. http://dx.doi. org $/ 10.1038 / \mathrm{cmi} .2010 .67$

[3] MARIAT D, FIRMESSE O, LEVENEZ F, GUIMARAES VD, $\mathrm{SOKOL} \mathrm{H}$ et al. The Firmicutes/Bacteroidetes ratio of the human microbiota changes with age. BMC Microbiology 2009; 9: 123. http://dx.doi.org/10.1186/1471-2180-9-123

[4] ROGER LC, MCCARTNEY AL. Longitudinal investigation of the faecal microbiota of healthy full-term infants using fluorescence in situ hybridization and denaturing gradient gel electrophoresis. Microbiology 2010; 156: 3317-28. http:// dx.doi.org/10.1099/mic.0.041913-0

[5] ROGER LC, COSTABILE A, HOLLAND DT, HOYLES L, MCCARTNEY AL. Examination of faecal Bifidobacterium populations in breast- and formula-fed infants during the first
18 months of life. Microbiology 2010; 156: 3329-41. http:// dx.doi.org/10.1099/mic.0.043224-0

[6] FAVIER CF, VAUGHAN EE, DE VOS WM, AKKERMANS ADL. Molecular monitoring of succession of bacterial communities in human neonates. Appl. Environ. Microbiology 2002; 68: 219-226. http://dx.doi.org/10.1128/AEM.68.1.219226.2002

[7] TOJO R, SUAREZ A, CLEMENTE MG, DE LOS REYESGAVILAN CG, MARGOLLES A et al. Intestinal microbiota in health and disease: Role of bifidobacteria in gut homeostasis. World J Gastroenterol. 2014; 20(41): 15163-15176. http:// dx.doi.org/10.3748/wjg.v20.i41.15163

[8] HORNEF MW, WICK MJ, RHEN M, NORMARK S. Bacterial strategies for overcoming host innate and adaptive immune responses. Nature Immunology 2002; 3: 1033-1040. http:// dx.doi.org/10.1038/ni1102-1033

[9] PROCTOR LM. The Human Microbiome Project in 2011 and beyond. Cell Host Microbe. 2011; 10: 287-91. http://dx.doi. org/10.1016/j.chom.2011.10.001

[10] PETERSON J, GARGES S, GIOVANNI M, MCINNES P, WANG et al. The NIH Human Microbiome Project. Genome Res. 2009; 19: 2317-2323. http://dx.doi.org/10.1101/ gr.096651.109

[11] THE HUMAN MICROBIOME CONSORTIUM. A framework for human microbiome research. Nature 2012; 486: 215-221. http://dx.doi.org/10.1038/nature11209

[12] THE HUMAN MICROBIOME CONSORTIUM. Structure, function and diversity of the healthy human microbiome. Nature 2012; 486: 207-214. http://dx.doi.org/10.1038/nature 11234

[13] DING T, SCHLOSS PD. Dynamics and associations of microbial community types across the human body Nature 2014; 509(7500): 357-60. http://dx.doi.org/10.1038/ nature 13178

[14] TJALSMA H, BOLEIJ A, MARCHESI J, DUTILH B. A bacterial driver-passenger model for colorectal cancer: beyond the usual suspects. Nat Rev Microbiol 2012; 10: 575-582. http:// dx.doi.org/10.1038/nrmicro2819

[15] BECKER S, OELSCHLAEGER TA, WULLAERT A, VLANTIS K, PASPARAKIS M, et al. Bacteria Regulate Intestinal Epithelial Cell Differentiation Factors Both In Vitro and In Vivo. PLoS ONE 2013; 8: e55620. http://dx.doi.org/10.1371/ journal.pone.0055620

[16] FEARON ER. Molecular genetic of colorectal cancer. Annu Rev Pathol 2011; 6: 479- 507. http://dx.doi.org/10.1146/ annurev-pathol-011110-130235

[17] ECKBURG PB, BIK EM, BERNSTEIN CN, PURDOM E, DETHLEFSEN L, et al. Diversity of the human intestinal microbial flora. Science 2005; 308: 1635-8. http://dx.doi. org/10.1126/science.1110591

[18] PALMER J, FLINT S, BROOKS J. Bacterial cell attachment, the beginning of a biofilm. J Ind Microbiol Biotechnol. 2007; 34: 577-88. http://dx.doi.org/10.1007/s10295-007-0234-4

[19] DE MARTEL C, FRANCESCHI S. Infections and cancer: established associations and new hypotheses. Crit Rev Oncol Hematol. 2009 ;70: 183-94. http://dx.doi.org/10.1016/j. critrevonc.2008.07.021 
[20] PEEK RM Jr, BLASER MJ. Helicobacter pylori and gastrointestinal tract adenocarcinomas. Nat Rev Cancer. 2002; 2: 28-37. http://dx.doi.org/10.1038/nrc703

[21] PARSONNET J, HANSEN S, RODRIGUEZ L, GELB AB, WARNKE RA et al. Helicobacter pylori infection and gastric lymphoma. N Engl J Med. 1994; 330: 1267-71. http://dx.doi. org/10.1056/NEJM199405053301803

[22] VOGELMANN R, AMIEVA MR. The role of bacterial pathogens in cancer. Curr Opin Microbiol. 2007; 10: 76-81. http:// dx.doi.org/10.1016/j.mib.2006.12.004

[23] HOOPER LV, MACPHERSON AJ. Immune adaptations that maintain homeostasis with the intestinal microbiota. Nature Reviews Immunology 2010; 10: 159-169. http://dx.doi. org/10.1038/nri2710

[24] OOSTINDJER M, ALEXANDER J, AMDAM GV, ANDERSEN G, BRYAN NS et al. The role of red and processed meat in colorectal cancer development: a perspective. Meat Sci. 2014; 97: 583-96. http://dx.doi.org/10.1016/j. meatsci.2014.02.011

[25] CHAN AT. Giovannucci, E.L. Primary prevention of colorectal cancer. Gastroenterology 2010; 138: 2029-2043. http://dx.doi. org/10.1053/j.gastro.2010.01.057

[26] ZACKULAR JP, ROGERS MA, RUFFIN MT 4TH, SCHLOSS $\mathrm{PD}$. The human gut microbiome as a screening tool for colorectal cancer Cancer Prev Res (Phila). 2014; 7(11): 1112-21. http://dx.doi.org/10.1158/1940-6207.CAPR-14-0129

[27] CASTELLARIN M, WARREN RL, FREEMAN JD, DREOLINI L, KRZYWINSKI M et al. Fusobacterium nucleatum infection is prevalent in human colorectal carcinoma. Genome Res. 2012; 22: 299-306. http://dx.doi.org/10.1101/ gr.126516.111

[28] KOSTIC AD, CHUN E, MEYERSON M, GARRETT WS. Microbes and inflammation in colorectal cancer. Cancer Immunol Res. 2013; 1: 150-7. http://dx.doi.org/10.1158/23266066.CIR-13-0101

[29] LUPERCHIO SA, SCHAUER DB. Molecular pathogenesis of Citrobacter rodentium and transmissible murine colonic hyperplasia. Microbes Infect 2001; 3: 333-340. http://dx.doi. org/10.1016/S1286-4579(01)01387-9

[30] NEWMAN JV, KOSAKA AT, SHEPPARD BJ, FOX JG, SCHAUER DB. Bacterial Infection Promotes Colon Tumorigenesis in ApcMin/+ MiceThe Journal of Infectious Diseases 2001;184: 227-30. http://dx.doi.org/10.1086/321998

[31] ZHU K, DEVESA SS, WU H, ZAHM SH, JATOI I et al. Cancer incidence in the U.S. military population: comparison with rates from the SEER program. Cancer Epidemiol Biomarkers Prev 2009; 18: 1740-1745. http://dx.doi.org/10.1158/10559965.EPI-09-0041

[32] ZHANG B, IZADJOO M, HORKAYNE-SZAKALY I, MORRISON A, WEAR DJ. Medulloblastoma and Brucellosis - Molecular Evidence of Brucella sp in Association with Central Nervous System Cancer. J Cancer 2011; 12: 136-141. http://dx.doi.org/10.7150/jca.2.136

[33] ANTONIC V, STOJADINOVIC A, KESTER KE, WEINA PJ, BRUCHER BL et al. Significance of infectious agents in colorectal cancer development. J Cancer 2013; 4: 227-240. http://dx.doi.org/10.7150/jca.5835
[34] SHEN XJ, RAWLS JF, RANDALL T, BURCAL L, MPANDE $\mathrm{CN}$ et al. Molecular characterization of mucosal adherent bacteria and associations with colorectal adenomas. Gut Microbes. 2010; 1: 138-47. http://dx.doi.org/10.4161/ gmic.1.3.12360

[35] SWIDSINSKI A, KHILKIN M, KERJASCHKI D, SCHREIBER S, ORTNER M, et al. Association between intraepithelial Escherichia coli and colorectal cancer. Gastroenterology 1998; 115: 281-286. http://dx.doi.org/10.1016/S0016-5085(98)70194-5

[36] MEGO M, MAJEK J, KONCEKOVA R, EBRINGER L, CIERNIKOVA $S$ et al. Intramucosal bacteria in colon cancer and their elimination by probiotic strainEnterococcus faecium M-74 with organic selenium. Folia Microbiol (Praha) 2005;50: 443-7. http://dx.doi.org/10.1007/BF02931427

[37] ABDULAMIR AS, HAFIDH RR, MAHDI LK, AL-JEBOORI $\mathrm{T}, \mathrm{ABUBAKER} \mathrm{F}$. Investigation into the controversial association of Streptococcus gallolyticus with colorectal cancer and adenoma. BMC Cancer 2009; 9: 403. http://dx.doi. org/10.1186/1471-2407-9-403

[38] GUPTA A, MADANI R, MUKHTAR H. Streptococcus bovis endocarditis, a silent sign for colonic tumour. Colorectal Dis 2010; 12: 164-171. http://dx.doi.org/10.1111/j.1463-1318 .2009.01814.x

[39] GRILLOT-COURVALIN C, GOUSSARD S, COURVALIN, P. Bacteria as Gene Delivery Vectors for Mammalian Cells. Current Opinion in Biotechnology 1999; 10: 477-481. http:// dx.doi.org/10.1016/S0958-1669(99)00013-0

[40] WATERS VL. Conjugation between bacterial and mammalian cells. Nat Genet. 2001; 29: 375-6. http://dx.doi.org/10.1038/ $\underline{\text { ng779 }}$

[41] HOTOPP JCD, CLARK ME, OLIVEIRA DC, FOSTER JM, FISCHER P et al. Widespread lateral gene transfer from intracellular bacteria to multicellular eukaryotes. Science. 2007; 317: 1753-6. http://dx.doi.org/10.1126/ science. 1142490

[42] HOTOPP JCD. Horizontal gene transfer between bacteria and animals. Trends Genet. 2011; 27: 157-63. http://dx.doi. org/10.1016/j.tig.2011.01.005

[43] LURIE-WEINBERGER MN, GOMEZ-VALERO L, MERAULT N, GLOCKNER G, BUCHRIESER C et al. The origins of eukaryotic like proteins in Legionella pneumophila. Int J Med 2010; 300: 470-81.

[44] LURIE-WEINBERGER MN, PEERI M, TULLER T, GOPHNA U. Extensive Inter-Domain Lateral Gene Transfer in the Evolution of the Human Commensal Methanosphaera stadtmanae Front Genet. 2012; 3: 182.

[45] RILEY DR, SIEBER KB, ROBINSON KM, WHITE JR, GANESAN A et al. Bacteria-Human Somatic Cell Lateral Gene Transfer Is Enriched in Cancer Samples. PLoS Comput Biol 2013; 9: e1003107. http://dx.doi.org/10.1371/journal. pcbi. 1003107

[46] HOLEC V, CIERNIKOVA S, WACHSMANNOVA L, ADAMCIKOVA Z, HAINOVA K ET AL. Analysis of bacteria from intestinal tract of FAP patients for the presence of APC-like sequences. Med Sci Moni.2012; 18: CR486-492. http://dx.doi.org/10.12659/MSM.883268 
[47] HAINOVA K, ADAMCIKOVA Z, CIERNIKOVA S, STEVURKOVA V, TYCIAKOVA $S$ et al. Intestinal flora of FAP patients containing APC-like sequences. Neoplasma. 2014; 61: 283-90. http://dx.doi.org/10.4149/neo 2014036

[48] FAO,WHO: Evaluation of health and nutritional properties of probiotics in food, including powder milk with live lactic acid bacteria. Food and Agricultural Organization of United Nations and World Health Organization Expert Consultation report 2001.

[49] HUEBNER ES, SURAWICZ CM. Probiotics in the prevention and treatment of gastrointestinal infections. Gastroenterol Clin North Am 2006; 35: 355-65. http://dx.doi.org/10.1016/j. gtc. 2006.03.005

[50] SCALDAFERRI F, GERARDI V, LOPETUSO LR, DEL ZOMPO F, MANGIOLA F, et al. Gut microbial flora, prebiotics, and probiotics in IBD: their current usage and utility. Biomed Res Int. 2013; 435268.

[51] SAKAMOTO I, IGARASHI M, KIMURA K, TAKAGI A, MIWA T et al. . Suppressive effect of Lactobacillus gasseri OLL 2716 (LG21) on Helicobacter pylori infection in humans. J Antimicrob Chemother. 2001; May;47: 709-10. http://dx.doi. org/10.1093/jac/47.5.709

[52] HICKSON, D'SOUZA AL, MUTHU N, ROGERS TR, WANT $S$ et al. Use of probiotic Lactobacillus preparation to prevent diarrhoea associated with antibiotics: randomised double blind placebo controlled trial. BMJ. 2007; 335: 80. http:// dx.doi.org/10.1136/bmj.39231.599815.55

[53] HICKSON M. Probiotics in the prevention of antibioticassociated diarrhoea and Clostridium difficile infection. Therap Adv Gastroenterol. 2011;4: 185-97. http://dx.doi. org/10.1177/1756283X11399115

[54] DELIA P, SANSOTTA G, DONATO V, MESSINA G, FROSINA $P$ et al. Prevention of radiation-induced diarrhea with the use of VSL\#3, a new high-potency probiotic preparation. Am J Gastroenterol. 2002; 97: 2150-2. http://dx.doi. org/10.1111/j.1572-0241.2002.05946.x

[55] URBANCSEK H, KAZAR T, MEZES I, NEUMANN K. Results of a double-blind, randomized study to evaluate the efficacy and safety of Antibiophilus in patients with radiationinduced diarrhoea. Eur J Gastroenterol Hepatol. 2001; 13: 391-396. http://dx.doi.org/10.1097/00042737-200104000$\underline{00015}$

[56] ROUND JL, MAZMANIAN SK. The gut microbiota shapes intestinal immune responses during health and disease. Nat Rev Immunol. 2009; 9: 313-23. http://dx.doi.org/10.1038/ $\underline{\text { nri2515 }}$

[57] MA EL, CHOI YJ, CHOI J, POTHOULAKIS C, RHEE SH et al. The anticancer effect of probiotic Bacillus polyfermenticus on human colon cancer cells is mediated through ErbB2 and ErbB3 inhibition. Int J Cancer. 2010; Aug 15; 127: $780-90.4$

[58] VAN LOO J, CLUNE Y, BENNETT M, COLLINS JK. The SYNCAN project: goals, set-up, first results and settings of the human intervention study. Br J Nutr 2005; 93 Suppl 1: S91-8. http://dx.doi.org/10.1079/BJN20041353

[59] PALA V, SIERI S, BERRINO F, VINEIS P, SACERDOTE C et al. .Yogurt consumption and risk of colorectal cancer in the Italian European prospective investigation into cancer and nutrition cohort. Int J Cancer. 2011; 129: 2712-9. http:// dx.doi.org/10.1002/ijc.26193

[60] WOLLOWSKI I, JI ST, BAKALINSKY AT, NEUDECKER C, POOL-ZOBEL BL. Bacteria used for the production of yogurt inactivate carcinogens and prevent DNA damage in the colon of rats. J Nutr.1999; 129: 77-82.

[61] MEgO M, HOLEC V, DRGONA L, HAinova K, CIERNIKOVA $S$ et al. . Probiotic bacteria in cancer patients undergoing chemotherapy and radiation therapy. Complement Ther Med. 2013; 21: 712-23. http://dx.doi.org/10.1016/j. ctim.2013.08.018

[62] MEGO M, EBRINGER L, DRGONA L, MARDIAK J, TRUPL $\mathrm{J}$ et al. Prevention of febrile neutropenia in cancer patients by probiotic strain Enterococcus faecium M-74. Pilot study phase I. Neoplasma 2005; 52: 159-64.

[63] MEGO M, KONCEKOVA R, MIKUSKOVA E, DRGONA L, EBRINGER L et al. . Prevention of febrile neutropenia in cancer patients by probiotic strain Enterococcus faecium M-74. Phase II study. Support Care Cancer. 2006; 14: 285-90. http://dx.doi.org/10.1007/s00520-005-0891-7

[64] MEgO M, CHOVANEC J, ANDREZALOVA I, KONKOLOVSKY P, MIKULOVA $\mathrm{M}$ et al. Prevention of irinotecan-induced diarrhea by probiotics: Randomized double-blind, placebo-controlled phase III study. J Clin Oncol 2014; 32: 5s (suppl; abstr 9611).

[65] REDMAN MG, WARD EJ, PHILLIPS RS. The efficacy and safety of probiotics in people with cancer: a systematic review. Ann Oncol. 2014; 25: 1919-29. http://dx.doi.org/10.1093/ annonc/mdu106

[66] GARMORY HS, LEARY SE, GRIFFIN KF, WILLIAMSON $\mathrm{ED}, \mathrm{BROWN}$ KA et al. . The use of live attenuated bacteria as a delivery system for heterologous antigens. J Drug Target. 2003; 11: 471-9. http://dx.doi.org/10.1080/10611860410001670008

[67] CRONIN M, STANTON RM, FRANCIS KP, TANGNEY $M$. Bacterial vectors for imaging and cancer gene therapy: a review. Cancer Gene Ther. 2012; 19: 731-40. http://dx.doi. org $/ 10.1038 /$ cgt.2012.59

[68] BABAN CH K, CRONIN M, O'HANLON D, O'SULLIVAN GC, TANGNEY M. Bacteria as vectors for gene therapy of cancer. Bioeng Bugs. 2010; 1: 385-394. http://dx.doi.org/10.4161/ bbug.1.6.13146

[69] CELEC P, GARDLIK R, PALFFY R, HODOSY J, STUCHLIK $S$ et al. The use of transformed Escherichia coli for experimental angiogenesis induced by regulated in situ production of vascular endothelial growth factor-an alternative gene therapy. Med Hypotheses. 2005; 64: 505-11. http://dx.doi. org/10.1016/j.mehy.2004.07.039

[70] PALFFY R, GARDLIK R, HODOSY J , BEHULIAK M , RESKO $P$ et al. .Bacteria in gene therapy: bactofection versus alternative gene therapy Gene Therapy 2006; 13: 101-105. http://dx.doi.org/10.1038/sj.gt.3302635

[71] CRONIN M, MORRISSEY D, RAJENDRAN S, EL MASHAD SM, VAN SINDEREN D et al. Orally administered bifidobacteria as vehicles for delivery of agents to systemic tumors. Mol Ther. 2010; 18: 1397-1407. http://dx.doi.org/10.1038/ $\underline{\text { mt.2010.59 }}$ 
[72] ADAMCIKOVA Z, WACHSMANNOVA L, HAINOVA K, STEVURKOVA V, HOLEC V et al. Study of the APC gene function in the mouse APC+/APC1638N model. Neuro Endocrinol Lett. 2012; 3326-33.

[73] VASSAUX G, NITCHEU J, JEZZARD S, LEMOINE NR. Bacterial gene therapy strategies. J Pathol. 2006; 208: 290-298. http://dx.doi.org/10.1002/path.1865

[74] XIANG S, FRUEHAUF J, LI CHJ. Short hairpin RNA-expressing bacteria elicit RNA interference in mammals. Nature Biotechnology 2006; 24: 697-702. http://dx.doi.org/10.1038/ nbt1211

[75] SIZEMORE DR, BRANSTROM AA, SADOFF JC. Attenuated Shigella as a DNA delivery vehicle for DNA-mediated immunization. Science 1995; 270: 299-302. http://dx.doi. org/10.1126/science.270.5234.299
[76] BUTTARO C, FRUEHAUF JH. Engineered E. coli as vehicles for targeted therapeutics. Curr Gene Ther. 2010; 10: 27-33. http://dx.doi.org/10.2174/156652310790945593

[77] NARAYANAN K, LEE CW, RADU A, SIM EU. Escherichia coli bactofection using Lipofectamine. Anal Biochem. 2013; 2: 142-4. http://dx.doi.org/10.1016/j.ab.2013.04.010

[78] ZURITA-TURK M, DEL CARMEN S, SANTOS AC, PEREIRA VB, CARA DC et al. Lactococcus lactis carrying the pValac DNA expression vector coding for IL-10 reduces inflammation in a murine model of experimental colitis. BMC Biotechnol. 2014; 14: 73. http://dx.doi.org/10.1186/1472-6750-14-73

[79] GUIMARAES V, INNOCENTIN S, CHATEL JM, LEFEVRE F, LANGELLA P, et al. A new plasmid vector for DNA delivery using lactococci. Genetic Vaccines and Therapy 2009; 7: 4. http://dx.doi.org/10.1186/1479-0556-7-4 